\title{
Exotic invaders of the meso-oligohaline zone of estuaries in the Netherlands: why are there so many?
}

\author{
Wim J. Wolff \\ University of Groningen, Department of Marine Biology, PO Box 14, \\ 9750 AA Haren, The Netherlands
}

\begin{abstract}
The numbers of exotic species introduced into brackish waters (5-20 psu) and highsalinity waters (>20 psu) in the Netherlands are hypothesized to reflect species richness in such waters elsewhere in the world. Notwithstanding the fact that species numbers in brackish waters all over the world are lower than in high-salinity waters, the numbers of introduced species in these waters in the Netherlands are about equal. Alternative hypotheses to explain this phenomenon are: (1) because most ports are situated in brackish regions, brackish-water species stand a better chance of being transported; (2) because brackish-water species are more tolerant of conditions in ballast water tanks, these species have a better chance of being transported alive than high-salinity species; and (3) because brackish waters have few species, it is easier for an introduced species to establish itself in brackish waters. None of the latter three hypotheses can be rejected and probably they all play a part in explaining the phenomenon. The third hypothesis, however, seems most likely.
\end{abstract}

\section{INTRODUCTION}

The well-known relationship between salinity and species numbers was first demonstrated by Remane $(1934,1971)$. High species numbers occur both in freshwater and seawater, whereas brackish waters are characterized by a low number of species, some of which are characteristic of brackish waters. Although originally the relationship shown by Remane was based on data from the Baltic and other regions of northern Europe, the relationship also appears to hold for many other parts of the world, e.g. the Black Sea (Remane, 1971), the Atlantic coast of North America (Boesch, 1972), and South Africa (Day, 1981). I assume that low species numbers are a feature of brackish waters all over the world.

In relation to the introduction of exotic species to other parts of the world it might be assumed as a first approximation that brackish-water species have the same chance of being transported as have high-salinity species or freshwater species. Hence, I formulate as an hypothesis to be tested that the number of exotic species introduced into brackish waters is considerably less than the number of such species introduced into high-salinity coastal waters.

As brackish-water species I consider those inhabiting parts of estuaries and lagoons with a salinity normally between about 5 and 20 psu. High-salinity species are defined 
as species living in the parts of estuaries with a salinity between about 20 psu and that of full-strength seawater.

\section{MATERIALS AND METHODS}

This study has been based on existing data on benthic macrofauna (>1 mm) from three estuarine and lagoonal areas in the Netherlands. Included in this survey are species from the Cnidaria, Mollusca, Polychaeta, Oligochaeta, Decapoda, Isopoda, Amphipoda and Cirripedia.

The first of the areas investigated is the estuarine area of the rivers Rhine, Meuse and Scheldt in the southwestern part of the Netherlands, collectively known as the Delta area. Until 1970 this area was characterized by a number of well-developed macro- to mesotidal estuaries with large brackish-water and high-salinity zones as well as a large number of non-tidal brackish water ponds and pools. The benthic macrofauna of this area was described in considerable detail by Wolff $(1973$, and references therein) with the exception of the Oligochaeta. The latter group was described by Verdonschot (1981) and Verdonschot et al. (1982). Additional data were derived from Braber \& Borghouts (1977) (sea anemones), Heerebout (1970) and Jebram (1968) (Bryozoa), and Swennen (1961) (Nudibranchia).

The second area is the former Zuiderzee. This was a large (about $4000 \mathrm{~km}^{2}$ ) brackish-water area in the centre of the Netherlands with a transition to the Wadden Sea in the northern part of the Netherlands which had and has a higher salinity. The Zuiderzee was dammed and turned into a freshwater lake in 1932, but before a detailed examination of its flora and fauna had been made. This has resulted in two Dutch-language books (Redeke, 1922, 1936). Later, a third book (De Beaufort, 1954) was published on the process of change towards a freshwater lake; this book also contains information on the situation before the dam was built in 1932. The Zuiderzee formed a transition between a meso- to microtidal estuary in the north and a more lagoon-like water body with a very limited tidal range in the south. After its freshening in 1932 the Noordzeekanaal between Amsterdam and the North Sea remained a brackish-water habitat.

The third area is the Ems estuary with the Dollard embayment in the northeastern part of the Netherlands. This is a macro- to mesotidal estuary with extended high-salinity and brackish-water areas. Dittmer (1981) and Michaelis (1981) summarized the occurrence and distribution of the benthic fauna in this estuary based on earlier publications as well as unpublished data. Since these two authors also describe the benthic fauna of the nearby Weser estuary in Germany in their publications, this estuary is included in this paper as well.

In addition to the reviews on the benthic fauna of the three estuarine areas mentioned above, I have collected all published data (many in Dutch-language periodicals) on introductions of exotic species into high-salinity and brackish waters in the Netherlands. Exotic species have been defined as species originally not occurring along the Atlantic coasts of Europe (Gibraltar to North Cape), brought into the area through some sort of human activity, and having established reproducing populations. Hence, Mediterranean and Ponto-Caspian species have been considered as exotics. Those species occurring between Gibraltar and the North Cape are assumed to be able to arrive in 
Dutch coastal waters by natural processes (mainly transport by currents); if they do not occur there, some other environmental factor apparently restricts their distribution.

\section{RESULTS}

Table 1 lists the introduced species occurring in brackish waters in the Netherlands. Table 2 lists the introduced species occurring in the high-salinity parts of the estuaries studied. Note that some species are normal inhabitants of both types of waters. For the time being I estimate that 16 exotic species have established themselves permanently or at least for several years in the brackish waters of the Netherlands, whereas 14 exotic species are known to have established themselves in the waters with a higher salinity.

The total number of species of the taxonomic groups considered in the brackish waters is about 80 (Verdonschot, 1981; Verdonschot et al., 1982; Wolff, 1973 and unpublished work), whereas the total number in the higher-salinity waters is about 250 (Verdonschot, 1981; Wolff, 1973 and unpublished work). Hence, the percentage of exotic species in Dutch brackish waters is about $20 \%$, whereas the percentage in high-salinity waters is nearly $6 \%$.

Table 1. Species known or suspected of having been introduced into brackish waters of the Netherlands. $T=$ occurs in tidal waters; $S=$ occurs in stagnant waters; $E=$ established; $E$ ? = establishment uncertain. Note that the former Zuiderzee ceased to exist in 1932; hence, any species introduced later cannot have occurred in this water body. $(E)=$ introductions after 1932 in the brackish Noordzeekanaal. References denote major publications in which introduction of a species into the Netherlands is documented

\begin{tabular}{|c|c|c|c|c|c|}
\hline Species & Type & Delta & $\begin{array}{l}\text { Zuider- } \\
\text { zee }\end{array}$ & $\begin{array}{l}\text { Ems/ } \\
\text { Weser }\end{array}$ & References \\
\hline Cordylophora caspia & T S & E & E & E & Vervoort, 1964 \\
\hline Bimeria franciscana & $\mathrm{T}$ & E & $\bar{E}$ & E & Vervoort, 1964 \\
\hline Haliplanella lineata & $\mathrm{S}$ & $\mathrm{E}$ & - & - & $\begin{array}{l}\text { Braber \& Borghouts, } 1977 \\
\text { Faasse, } 1997\end{array}$ \\
\hline Potamopyrgus antipodarum & $T S$ & E & $E$ & E & Jutting, 1933 \\
\hline Corambe obscura & $\mathrm{TS}$ & - & $\mathrm{E}$ & - & Swennen \& Dekker, 1995 \\
\hline Mytilopsis leucophaeta & $\mathrm{S}$ & E & $\mathrm{E}$ & - & Jutting, 1943 \\
\hline Mya arenaria & $T$ & E & $\mathrm{E}$ & $E$ & Hessland, 1945 \\
\hline Marenzelleria cf wireni & $\mathrm{T}$ & E & - & $E$ & $\begin{array}{l}\text { Essink \& Kleef, 1988; } \\
\text { Bick \& Zettler, } 1997\end{array}$ \\
\hline Ficopomatus enigmaticus & $\mathrm{s}$ & $\mathrm{E}$ & $(E)$ & $E$ & $\begin{array}{l}\text { Wolff, } 1969 ; \text {, Van der Velde } \\
\text { et al., } 1993\end{array}$ \\
\hline Rhithropanopeus harrisii & T S & $\mathrm{E}$ & E & - & Buitendijk \& Holthuis, 1949 \\
\hline Eriocheir sinensis & $\mathrm{T}$ & E & - & $\mathrm{E}$ & Kamps, 1937 \\
\hline Callinectes sapidus & $\mathrm{TS}$ & $\mathrm{E}$ ? & (E) & - & $\begin{array}{l}\text { Timmermans \& Melchers, } \\
1992\end{array}$ \\
\hline Gammarus tigrinus & $\mathrm{T}$ & $\mathrm{E}$ & - & $\mathrm{E}$ & Nijssen \& Stock, 1966 \\
\hline Balanus amphitrite & $\mathrm{S}$ & E? & & & $\begin{array}{l}\text { Borghouts-Biersteker, } 1969 ; \\
\text { Vaas, } 1975 ; \text { Faasse, } 1996\end{array}$ \\
\hline Balanus eburneus & $T$ ? $\mathrm{S}$ & $E ?$ & $E ?$ & & Stock, 1995 \\
\hline Balanus improvisus & $\mathrm{T}$ & E & E & $\mathrm{E}$ & Barnes, 1994 \\
\hline
\end{tabular}


Table 2. Species known or suspected of having been introduced into high-salinity waters of the Netherlands. $T=$ occurs in tidal waters; $L=$ occurs in stagnant waters; $E=$ established; $E$ ? = establishment doubtful; $\mathrm{NE}=$ not established. References denote publications in which introduction of a species into the Netherlands is documented

\begin{tabular}{|c|c|c|c|c|c|}
\hline Species & Type & Delta & $\begin{array}{l}\text { Zuider- } \\
\text { zee }\end{array}$ & $\begin{array}{l}\text { Ems/ } \\
\text { Weser }\end{array}$ & References \\
\hline Haliplanella lineata & $\mathrm{TS}$ & $\mathrm{E}$ & $E$ & - & Faasse, 1997 \\
\hline Crepidula fornicata & $\mathrm{T}$ & E & $E$ & $E$ & Jutting. 1933 \\
\hline Crassostrea gigas & $T$ & $E$ & $\mathrm{E}$ & - & Drinkwaard, 1999 \\
\hline Mercenaria mercenaria & $\mathrm{T}$ & NE & - & - & Personal observations (1961) \\
\hline Petricola pholadiformis & $\mathrm{T}$ & $\mathrm{E}$ & $\mathrm{E}$ & $\mathrm{E}$ & Jutting, 1943 \\
\hline Teredo navalis & $\mathrm{T}$ & $\mathrm{E}$ & $E$ & & Jutting, 1943 \\
\hline $\begin{array}{l}\text { Ensis directus } \\
\qquad(\text { E. americanus })\end{array}$ & $\mathrm{T}$ & $\mathrm{E}$ & $\mathrm{E}$ & $E$ & Essink, 1985 \\
\hline Mya arenaria & $\mathrm{T}$ & $\mathrm{E}$ & $E$ & $E$ & Hessland, 1945 \\
\hline Polydora hoplura & $\mathrm{T}$ & NE & - & - & Korringa, 1951 \\
\hline Hydroides elegans & $\mathrm{S}$ & NE & - & - & $\begin{array}{l}\text { Ten Hove, } 1974 ; \\
\text { Ten Hove \& Lucas, } 1996\end{array}$ \\
\hline Janua brasiliensis & $\mathrm{S}$ & $\mathrm{E} ?$ & & & Critchley \& Thorp, 1985 \\
\hline Caprella macho & $\mathrm{T}$ & $\mathrm{E} ?$ & & & Platvoet et al., 1995 \\
\hline Callinectes sapidus & $\mathrm{T}$ & $\mathrm{E}$ ? & & & $\begin{array}{l}\text { Craeymeersch \& } \\
\text { Kamermans, } 1996\end{array}$ \\
\hline Eriocheir sinensis & $\mathrm{T}$ & $\mathrm{E}$ & $\mathrm{E}$ & $\mathrm{E}$ & Kamps, 1937 \\
\hline Elminius modestus & $\mathrm{T}$ & $\mathrm{E}$ & $E$ & $\mathrm{E}$ & Den Hartog, 1953 \\
\hline Balanus amphitrite & $\mathrm{S}$ & $\mathrm{E} ?$ & - & - & $\begin{array}{l}\text { Borghouts-Biersteker, } 1969 \\
\text { Vaas, } 1975_{i} \text { Faasse, } 1996\end{array}$ \\
\hline
\end{tabular}

\section{DISCUSSION AND CONCLUSIONS}

The hypothesis that the number of introduced species in brackish waters will be lower than that in high-salinity waters because the latter type of waters has more species available for transport can be rejected. Before I try to find alternative explanations I will consider the quality of my data.

Wolff (1973), Vaas (1975), Den Hartog \& Van der Velde (1987) and Wolff (1992) have previously provided earlier lists of species introduced into the Netherlands. The differences between their lists and the lists in this paper are due to the exclusion in this paper of (1) freshwater species, (2) a number of taxonomic groups (e.g. Copepoda, Tunicata, Pisces, Algae), (3) planktonic species, and (4) introduced species which are native to other parts of the Atlantic coastline of Europe (e.g. Branchiomma bombyx, Crassostrea angulata). I conclude that Dutch researchers agree on which exotic marine and brackish-water species have been introduced into the Netherlands. The only exception is Orchestia platensis, which Den Hartog \& Van der Velde (1987) consider an introduced brackish-water species. However, Den Hartog (1963) mentions O. platensis only from a saltmarsh near Den Oever in the Dutch Wadden Sea, i.e. the marine part of the former Zuiderzee system, and for that reason I doubt whether it should be considered a brackish-water species. Hence, it has not been listed in Table 1 or 2. 
As well as the species listed in Tables 1 and 2, cryptogenic species might be present. This category is not well researched so it is not possible to present lists at this moment. However, for brackish waters the bryozoans Bowerbankia gracilis, Victorella pavida, and Valkeria uva as well as the mud snail Heleobia stagnorum might be considered as such. For the first three species this is concluded from their cosmopolitan distribution, for the latter one from its occurrence in only one isolated locality in the Netherlands (Bank et al., 1979).

Since our first hypothesis had to be rejected, alternative hypotheses can be looked for. Three prime candidates are:

1. Because most ports are situated in brackish regions, brackish-water species stand a better chance of being transported.

2. Because brackish-water species are more tolerant of conditions in ballast water tanks, these species have a better chance of being transported alive than high-salinity species.

3. Because brackish waters have few species, it is easier for an introduced species to establish itself in brackish waters (Wolff, 1973).

It seems a reasonable assumption that most ports situated on estuaries nowadays originated on the freshwater tidal reaches of these estuaries (e.g. London, Rotterdam, Antwerp, Hamburg, Baltimore, Calcutta). Here, fresh water was available for consumption by man and animals, whereas sea-going ships could still reach these locations with the flood tide. In the course of their development these ports will have expanded on the downstream side of their original location, whereas dredging activities will have deepened the estuarine channels. Both activities will have resulted in promoting brackish conditions in the ports. Indeed, many harbour basins nowadays contain brackish water. This century the seaward movement of ports has resulted in the creation of a few deepwater ports, which are usually situated in areas with full strength seawater. Thus, at first sight the hypothesis that the high number of introduced brackish-water species reflects the location of ports along estuarine gradients seems to be confirmed. I do not see a possibility to test this hypothesis now, although in future the seaward movement of ports might result in a relatively higher introduction rate of high-salinity species.

The second hypothesis, higher tolerance of brackish-water species for ballast-water tank conditions, is supported by physiological data (Vernberg, 1983). Estuarine species can be characterized broadly as being more euryhaline and more eurythermal than open-ocean forms. Many have evolved considerable tolerance for oxygen deprivation. As a group, these organisms have evolved a wide range of physiological adaptations that permit them to utilize the fluctuations of the estuarine environment to their advantage. There is no doubt that the same species will be better adapted to temporary life in ballast water tanks than high-salinity species. However, how important have these adaptations been in facilitating transport? Ballast water has been used since the $1880 \mathrm{~s}$ (Carlton \& Geller, 1993). Of the species listed in Table 1, at least four species occurred in Dutch waters before this date and, hence, were probably not transported in ballast water - Mya arenaria, which was introduced many centuries ago (Hessland, 1945; Petersen et al., 1992); Rhithropanopeus harrisii, which was described as a new species (Pilumnus tridentatus Maitland) from the former Zuiderzee in 1874; and Corambe ob- 
scura which was described as a new species (Corambe batava Kerbert) from the former Zuiderzee in 1886, but the specimens were discovered as early as 1881 . Also, Cordylophora caspia occurred in Dutch waters as early as 1874 (Vervoort, 1946). In addition, species like Haliplanella lineata, Ficopomatus enigmaticus and Balanus spp. may have been transported on ship hulls. Although the hypothesis that brackish-water species are more easily transported in ballast water because of their higher physiological tolerance cannot be refuted, my data suggest that at least half and probably even more of the introduced brackish-water species have been transported by means other than ballast water.

The third hypothesis states that brackish waters are easily invaded, because only few species inhabit this habitat. Dutch (and NW European) brackish water, thus, should have empty niches. The existence of empty niches can be assumed, based on the following exemplary observations. A few centuries ago, no species of crabs occurred in the brackish waters in the Netherlands or elsewhere in Europe. Nowadays, at least three different species (Callinectes, Eriocheir, Rhithropanopeus) occur. Similarly, filter-feeding molluscs were absent from tidal brackish waters in NW Europe. In this case, only one species $(M Y a)$ is present now. Another argument that can be raised is that no introduction of exotic species has resulted in the extinction of native brackish-water species, but this is also true for the high-salinity introductions (Wolff, to be published). Again, it will be difficult to test this hypothesis, but on the other hand we have no arguments to contradict it.

In conclusion, I believe that of the three hypotheses formulated above, all may have played their part in enhancing the number of exotic brackish-water species in Dutch (and NW European) brackish waters, but that the last one (empty niches) seems most likely.

\section{LITERATURE CITED}

Bank, R. A., Butot, L. J. M. \& Gittenberger, E., 1979. On the identity of Helix stagnorum Gmelin, 1791, and Turbo ventrosus Montagu, 1803 (Prosobranchia, Hydrobiidae). - Basteria 43, 51-60.

Barnes, R. S. K., 1994. The brackish-water fauna of Northwestern Europe. Cambridge University Press, Cambridge, 287 pp.

Bick, A. \& Zettler, M. L., 1997. On the identity and distribution of two species of Marenzelleria (Polychaeta, Spionidae) in Europe and North America. - Aquat. Ecol. 31, 137-148.

Boesch, D. F., 1972. Species diversity of marine macrobenthos in the Virginia area. - Chesapeake Sci. 13, 206-211.

Borghouts-Biersteker, C. H., 1969. Balanus amphitrite amphitrite Darwin in Nederland (Crustacea, Cirripedia). - Zoöl. Bijdr. 11, 4-7.

Braber, L. \& Borghouts, C. H., 1977. Distribution and ecology of Anthozoa in the estuarine region of the rivers Rhine, Meuse, and Scheldt. - Hydrobiologia 52, 15-21.

Buitendijk, A. M. \& Holthuis, L. B., 1949. Note on the Zuiderzee crab, Rhithropanopeus harrisii (Gould) ssp. tridentatus (Maitland). - Zool. Meded. 30, 95-106.

Carlton, J. \& Geller, J. B., 1993. Ecological roulette: the transport of nonindigenous marine organisms. - Science 261, 78-82.

Craeymeersch, J. A. \& Kamermans, P., 1996. Waarnemingen van de blauwe zwemkrab Callinectes sapidus in de Oosterschelde. - Zeepaard 56, 21-22.

Critchley, A. T. \& Thorp, C. H., 1985. Janua (Dexiospira) brasiliensis (Grube) (Polychaeta, Spirorbidae): a new record from the south-west Netherlands. - Zool. Bijdr. 31, 1-7.

Day, J. H. (ed.), 1981. Estuarine ecology with particular reference to southern Africa. Balkema, Rotterdam, $411 \mathrm{pp}$. 
De Beaufort, L. F. (ed.), 1954. Veranderingen in de flora en fauna van de Zuiderzee (thans IJsselmeer) na de afsluiting in 1932. De Boer, Den Helder, 359 pp.

Den Hartog, C., 1953. Immigration, dissemination and ecology of Elminius modestus Darwin in the North Sea, especially along the Dutch coast. - Beaufortia 4(33), 1-20.

Den Hartog. C., 1963. The amphipods of the deltaic region of the rivers Rhine, Meuse and Scheldt in relation to the hydrography of the area. [1. The Talitridae. Neth. J. Sea Res. 2, 40-67.

Den Hartog, C. \& Van der Velde, G., 1987. Invasions by plants and animals into coastal, brackish and fresh water of the Netherlands. - Proc. K. Ned. Akad. Wet. C90, 31-37.

Dittmer, J.-D., 1981. The distribution of subtidal macrobenthos in the estuaries of the rivers Ems and Weser. In: Invertebrates of the Wadden Sea. Ed. by N. Dankers, H. Kühl \& W. J. Wolff. Balkema, Rotterdam, 188-206.

Drinkwaard, A. C., 1999. Introductions and developments of oysters in the North Sea area: a review. - Helgoländer Meeresunters. 52, 301-308.

Essink, K., 1985. On the occurrence of the American jack-knife clam Ensis directus (Conrad, 1843) (Bivalvia, Cultellidae) in the Dutch Wadden Sea. - Basteria 49, 73-80.

Essink, K. \& Kleef, H. L., 1988. Marenzelleria viridis (Verrill, 1873) (Polychaeta: Spionidae): a new record from the Ems estuary (The Netherlands/Federal Republic of Germany). - Zool. Bijdr. 38, 1-13.

Faasse, M., 1996. Diadumene luciae (Verril, 1869) en Balanus amphitrite Darwin, 1854 bij de koelwateruitlaat te Borssele. - Zeepaard 56, 73-75

Faasse, M., 1997. Nieuwe vindplaatsen van de groene golfbrekeranemoon (Diadumene luciae Verrill, 1898). - Zeepaard 57, 76-80.

Heerebout, G. R., 1970. Verspreidingsoecologie van de Bryozoa in het Deltagebied, speciaal in relatie tot het brakke water. Student report D1-1970. Delta Institute for Hydrobiological Research, Yerseke.

Hessland, 1., 1945. On the quarternary Mya period in Europe. Ark. Zool. (A) 37(8), 1-51.

Jebram, D., 1968. Zur Bryozoen-Fauna der Niederlande. - Neth. J. Sea Res.4, 86-94.

Jutting, T. van Benthem, n. 1933. Mollusca (I) B. Gastropoda Prosobranchia et Pulmonata. - Fauna Ned. 7. 1-387

Jutting, T. van Benthem, 1943. Mollusca C. Lamellibranchia. - Fauna Ned. 12, 1-477.

Kamps, L. F., 1937. De chineesche wolhandkrab in Nederland. PhD thesis, Rijksuniversiteit Groningen, 1-112.

Korringa, P., 1951.The shell of Ostrea edulis as a habitat. - Arch. Neerl. Zool. 10, 32-152.

Michaelis, H., 1981. Intertidal benthic animal communities of the estuaries of the rivers Ems and Weser. In: Invertebrates of the Wadden Sea. Ed. by N. Dankers, H. Kühl \& W. J. Wolff. Balkema, Rotterdam, 158-188.

Nijssen, H. \& Stock, J. H., 1966. The amphipod Gammarus tigrinus Sexton, 1939, introduced in the Netherlands (Crustacea). - Beaufortia 13(160), 197-206.

Petersen, K. S., Rasmussen, K. L., Heinemeier, J. \& Rudd, N., 1992. Clams before Columbus? - Nature 359, 679-680.

Platvoet, D., De Bruyne, R. H. \& Gmelig Meijling, A. W., 1995. Description of a new Caprella species from the Netherlands: Caprella macho nov. spec. (Crustacea, Amphipoda, Caprellidae). - Bull. Zool. Mus. Univ. Amst. 15(1), 1-4.

Redeke, H. C. (ed.), 1922. Flora en fauna der Zuiderzee. Monografie van een brakwatergebied. De Boer, Helder, $460 \mathrm{pp}$.

Redeke, H. C. (ed.), 1936. Flora en fauna der Zuiderzee. Monografie van een brakwatergebied. Supplement. De Boer, Den Helder, $157+80 \mathrm{pp}$.

Remane, A., 1934. Die Brackwasserfauna. - Verh. Dscht. Zool. Ges., 34-74

Remane, A., 1971 . Ecology of brackish water. In: Biology of brackish water. Ed. by A. Remane \& C. Schlieper. Schweizerbart'sche Verlagsbuchhandlung, Stuttgart, 1-210.

Stock, J. H., 1995. Vindplaatsen van de ivoorpok, Balanus eburneus, in Nederland. - Zeepaard 55, $19-22$.

Swennen, C., 1961. Data on distribution, reproduction and ecology of the nudibranchiate molluscs occurring in the Netherlands. - Neth. J. Sea Res. 1, 191-240. 
Swennen, C. \& Dekker, R., 1995. Corambe batava Kerbert, 1886 (Gastropoda Opisthobranchia), an immigrant in the Netherlands, with a revision of the family Corambidae. - J. Moll. Stud. 61, 97-107.

Ten Hove, H. A., 1974. Notes on Hydroides elegans (Haswell, 1883) and Mercierella enigmatica Fauvel, 1923, alien serpulid polychaetes introduced into the Netherlands. - Bull. Zool. Mus. Univ. Amst. 4, 45-51.

Ten Hove, H. A. \& Lucas, J. A. W., 1996. Kalkkokerwormen van Nederland. - Zeepaard 56, 30-52.

Timmermans, G. \& Melchers, M., 1992. Voelt de blauwe zwemkrab (Callinectes sapidus Rathbun, 1896) zich thuis in de Amerikahaven? - Zeepaard 52, 132-134.

Vaas, K. F. 1975. Immigrants among the animals of the Delta-area of the SW Netherlands. - Hydrobiol. Bull., 9, 114-119.

Van der Velde, G., Van der Gaag, M. \& Ten Hove, H. A., 1993. De exotische trompetkalkkokerworm (Ficopomatus enigmaticus (Fauvel)), een nieuwe kolonisator in het Noordzeekandal. Zeepaard 53, 62-70.

Verdonschot, P. F. M., 1981. Some notes on the ecology of aquatic oligochaetes in the Delta region of the Netherlands. - Arch. Hydrobiol. 92, 53-70.

Verdonschot, P. F. M., Smies, M. \& Sepers, A. B. J., 1982. The distribution of aquatic oligochaetes in brackish inland waters in the SW Netherlands. - Hydrobiologia 89, 29-38.

Vernberg, W. B., 1983. Responses to estuarine stress. In: Estuaries and enclosed seas. Ed. by B. H. Ketchum. Ecosystems of the world 26. Elsevier, Amsterdam, 43-64.

Vervoort, W., 1946. Hydrozod. A. Hydropoliepen. - Fauna Ned. 14, 1-336.

Vervoort, W., 1964. Notes on the distribution of Garveia franciscana (Torrey, 1902) and Cordylophora caspia (Pallas, 1771) in the Netherlands. - Zool. Meded. 39, 125-146.

Wolff, W. J., 1969. Mercierella enigmatica Fauvel, een borstelworm van het brakke water, voor het eerst in Nederland gevonden. - Levende Nat. 72, 85-92.

Wolff, W. J., 1973. The estuary as a habitat. An analysis of data on the soft-bottom macrofauna of the estuarine area of the rivers Rhine, Meuse, and Scheldt. - Zool. Verh., Leiden, 126, 1-242.

Wolff, W. J., 1992. Ecological developments in the Wadden Sed until 1990. - Neth. Inst. Sea Res. Publ. Ser. 20, 23-32. 